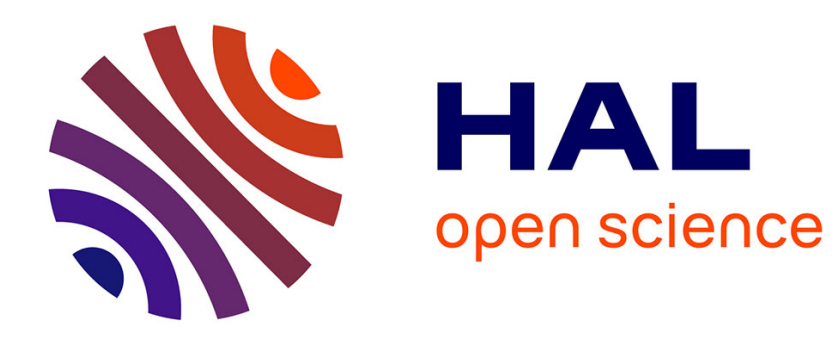

\title{
A pulsing system for heavy ion tandems
}

K.H. Purser

\section{- To cite this version:}

K.H. Purser. A pulsing system for heavy ion tandems. Revue de Physique Appliquée, 1977, 12 (10), pp.1578-1578. 10.1051/rphysap:0197700120100157800 . jpa-00244371

\section{HAL Id: jpa-00244371 https://hal.science/jpa-00244371}

Submitted on 1 Jan 1977

HAL is a multi-disciplinary open access archive for the deposit and dissemination of scientific research documents, whether they are published or not. The documents may come from teaching and research institutions in France or abroad, or from public or private research centers.
L'archive ouverte pluridisciplinaire HAL, est destinée au dépôt et à la diffusion de documents scientifiques de niveau recherche, publiés ou non, émanant des établissements d'enseignement et de recherche français ou étrangers, des laboratoires publics ou privés. 


\title{
A PULSING SYSTEM FOR HEAVY ION TANDEMS
}

\author{
K. H. PURSER
}

General Ionex Corporation, Ipswich, Massachusetts 01938, U.S.A.

Résumé. - On décrit le système de pulsation destiné à être installé à l'accélérateur NEC 20 MV de l'Institut de Recherche de l'Énergie Atomique du Japon.

Abstract. - The pulsing system for the Japanese Atomic Energy Research Institute 20 MV NEC tandem accelerator.

A pulsing system is described that will be installed in the Japanese Atomic Energy Research Institute $20 \mathrm{MV}$ tandem accelerator supplied by National Electrostatics Corporation. Particles entering the system at energies between $200 \mathrm{keV}$ and $350 \mathrm{keV}$ are chopped by a system of novel design which uses the two frequencies of $4 \mathrm{MHz}$ and $8 \mathrm{MHz}$ to produce beam pulses of $\sim 20$ ns duration and low energy spread. For heavy particles the chopping prior to bunching is achieved using a push/pull multiple plate deflector having twelve plates. Each plate is equipped with Rose shims to maximize the field uniformity and allow minimum capacitance. \pm 250 volt pulses are applied through a special transformer sequentially to the individual plate pairs to match the velocity of the beam particles. Two bunchers are used, one for light ions up to mass 60 and the second, within the pressure vessel, for masses between 40 and 240. For $20 \mathrm{MeV}$ protons the bunched pulses are expected to have FWHM less than $0.8 \mathrm{~ns}$. For iodine the in-tank heavy ion buncher is expected to produce pulses with a FWHM of less than $2.5 \mathrm{~ns}$. 